\title{
Caulerpa taxifolia var. distichophylla: a further stepping stone in the western Mediterranean
}

\author{
Mariagrazia Picciotto ${ }^{*}$, Clara Bertuccio, Salvatore Giacobbe and Nunziacarla Spanò
}

\begin{abstract}
Background: In the Mediterranean sea, about 150 species of invasive macroalgae are recorded until now these alien species have produced serious effect due to their capability to modify the physical and chemical property of the invaded habitats and to compete with native assemblages so as threatening the biodiversity and the ecosystem functioning.

Results: Based on morphological characters, the invasive green alga Caulerpa taxifolia var. distichophylla, has been recognised for the first time in the Strait of Messina area, off the northeastern coast of Sicily (Tyrrhenian Sea, western Mediterranean). This record confirms the rapid spread of this taxon from the Levantine area towards the western basins, and suggests a human-mediated dispersion. The new invader occurs in different habitats than C. taxifolia (Vahl) C. Agardh, and the respective habitats do not overlap in the Strait of Messina. A previously undescribed association of this species with tropical-subtropical phanerogams and green algae, is a further example of the global change-mediated reorganisation of Mediterranean benthic assemblages.
\end{abstract}

Conclusions: This record expands the known distribution range of this invasive green algae in Mediterranean Sea.

Keywords: Caulerpa distichophylla, Caulerpa taxifolia, Invasive species, Mediterranean Sea, Global change

\section{Background}

The spread of green algae belonging to the genus Caulerpa in the Mediterranean is considered one of the most important examples of biological invasion in recent years (Verlaque et al., 2004; Piazzi et al., 2005). In particular, Caulerpa taxifolia (Vahl) C. Agardh, which is not invasive in tropical regions, is known in the Mediterranean as an invasive lineage, the so called "aquarium strain", which spreads on a variety of substrata and forms dense beds (Meinesz et al. 1993) that represent a threat to benthic assemblages (Villele \& Verlaque, 1995; Ceccherelli \& Cinelli, 1997; Piazzi et al., 2001). Since the first Mediterranean report in 1984, C. taxifolia has rapidly colonised very large areas of the Ligurian and Tyrrhenian Seas (Meinesz et al., 2001) and has developed a major centre of diffusion in the Strait of Messina (Orestano et al. 2001). Since 2006, a small feather-like Caulerpa species

\footnotetext{
* Correspondence: mariagrazia.picciotto@hotmail.com

Department of Biological and Environmental Sciences, University of Messina, Viale F. Stagno d'Alcontres, 31, 98166 Messina, Italy
}

has been reported from southeastern Turkey (Cevik et al., 2007), followed by in southeastern Sicily (Jongma et al., 2013), Cyprus (Cicek 2013), southwestern and northwestern Sicily (Musco et al., 2014) and Malta (Schembri et al., 2015). This species is more slender and smaller than $C$. taxifolia and is also genetically distinct (Cevik et al., 2007; Jongma et al., 2013). Morphologically, it agrees with $C$. distichophylla Sonder, a species that originates from Southwest Australia but genetic data do not show strong differences between C. taxifolia and C. distichophylla such that the latter is at present considered a variety of the former, so that the taxon Caulerpa taxifolia var. distichophylla (Sonder) Verlaque, Huisman \& Procaccini has been proposed (Jongma et al., 2013). Although the taxonomic identity of Caulerpa taxifolia var. distichophylla is still uncertain, it is easily distinguishable morphologically from $C$. taxifolia, and a screening of their distribution might be useful to differentiate between their respective ecologies and potential invasiveness in the context of the changing Mediterranean Sea ecosystem (Bianchi et al., 2012). 
This paper reports the occurrence of C. taxifolia var. distichophylla from the northern borders of the Messina Strait, a crucial area in the spread of introduced species, since it directly connects the western and eastern basins.

The aims of this study were to delineate the local distribution of C. taxifolia var. distichophylla and to provide preliminary data on its density and biomass from the newly invaded area.

\section{Materials and methods}

The Strait of Messina area is characterised by a tidalinduced upwelling that determines a higher primary production compared to the adjacent Ionian and Tyrrhenian basins (Azzaro et al., 2007). The Strait is subject to irregular solid load inputs that are rapidly dispersed by currents. The sampled area is located in the northern part of the Strait, around Capo Rasocolmo, which is considered to be the northwestern border of the Strait. The coastline has a northwestern exposure, which determines an eastwards-oriented coastal current with marked coastal erosion and related degradation of the Posidonia oceanica L. Delile meadows (Giacobbe et al., 2001). The benthic communities of north-eastern Sicily have been investigated within the framework of the 2008/2009 University Programme, PRA, "Settlement dynamics and colonization of allochthonous assemblages in the Capo Peloro Lagoon". Field observations were carried out in summer 2013 by SCUBA divers both along the Sicilian and Calabrian coasts of the Messina Strait and in the Capo Peloro transitional waters. Further observations were carried out along the Tyrrhenian coasts between Capo Peloro and Capo Milazzo, and on the Ionian coast between Messina and Taormina. Caulerpa taxifolia var. distichophylla (Fig. 1) was recorded for the first time in Capo Rasocolmo in 2010 (Fig. 2), whereas its local distribution was mapped in 2013.

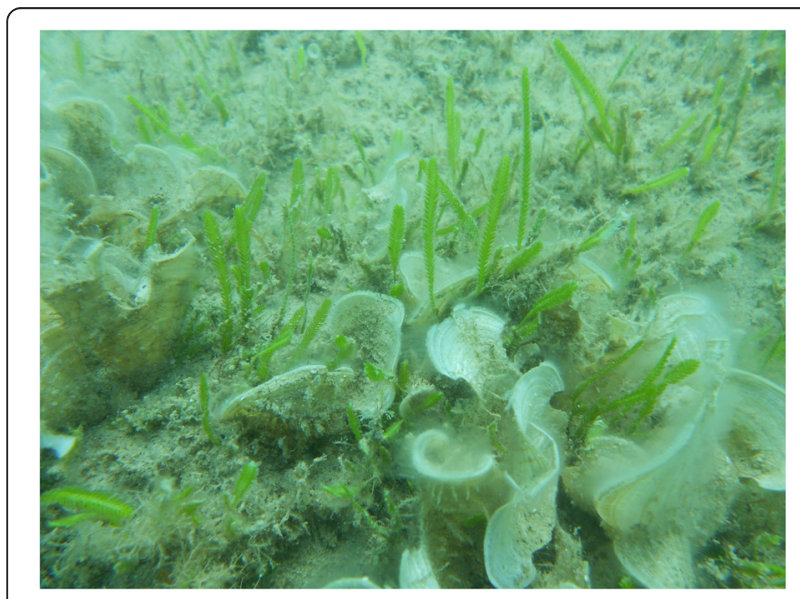

Fig. 1 In situ photograph of Caulerpa taxifolia var. distichophylla in the newly invaded area (AC site, October 2013)
In October 2013, four sampling sites were selected in the invaded area, which were not regularly spaced, because each sampling site had a different substratum. The distance between the San Saba (SS) and Acqualadrone (AC) sites is about $2.8 \mathrm{~km}$ and between the site Acqualadrone (AC) and Tono (TO) about $1.4 \mathrm{~km}$ (see Fig. 2). At each site, two stations spaced about $50 \mathrm{~m}$ apart were fixed at a depth of 3-6 m, corresponding to the bathymetric range covered by the alga. A further station was sampled at Tono (Tono B), due to the presence of a small Halophila stipulacea (Forsskål) Ascherson bed. In each station, three $20 \times 20 \mathrm{~cm}$ random replicates were collected to evaluate biomass (fresh weight, including rhizoids), the percentage cover was visually estimated by using a frame with twenty-five $4 \times 4$ subquadrats (Mangialajo et al., 2008) (three replicates).

Specimens of Caulerpa for morphological observation were hand-collected from each substatum type. Collections were examined while fresh, and were then preserved in $4 \%$ formaldehyde-buffered seawater. Samples were deposited at the laboratory of Benthos Ecology, Department of Biological and Environmental Sciences, Messina University, Italy.

\section{Results and discussion}

The collected thalli at all the above-mentioned sites had green, erect fronds, branched once or twice, $3-4 \mathrm{~cm}$ high and 2-4 mm broad; rachis, broad $0.5-1.0 \mathrm{~mm}$, cylindrical to the base and compressed towards the apex, showing oppositely arranged closely adjacent distichous pinnules, seldom tristichous; pinnules, $1-2 \mathrm{~mm}$ long and $0.2-0.4 \mathrm{~mm}$ broad, slightly compressed and curved at the tip; slender creeping stolons were $0.5-1.0 \mathrm{~mm}$ in diameter; frequent and short rhizoidal pillars about $3 \mathrm{~mm}$ long were also observed.

Specimens from this area corresponded well to the Caulerpa strain previously reported as C. taxifolia from Turkey (Cevik et al., 2007) and C. taxifolia var. distichophylla collected from Southern Sicily (Italy) (Jongma et al., 2013).

The new feather-like Caulerpa population (Fig. 1) covered a surface area of almost $0.6 \mathrm{~km}^{2}$. In the westernmost stations (S. Saba), boulders covered by a deposit of fine sands were colonised, whereas in the easternmost Tono, the amount of fine deposit was negligible. Both living (Acqualadrone) and dead (Tono B), Posidonia oceanica matte were also colonized, the latter in association with Halophila stipulacea. At both colonized sites, a moderate deposit of fine sand was observed. The western border of the Caulerpa formation is sharp, due to an abrupt transition towards a wave-exposed sandy barren area, whereas an irregular transition is observed eastwards. The percentage cover and biomass of $C$. taxifolia var. distichophylla were homogeneously distributed within 


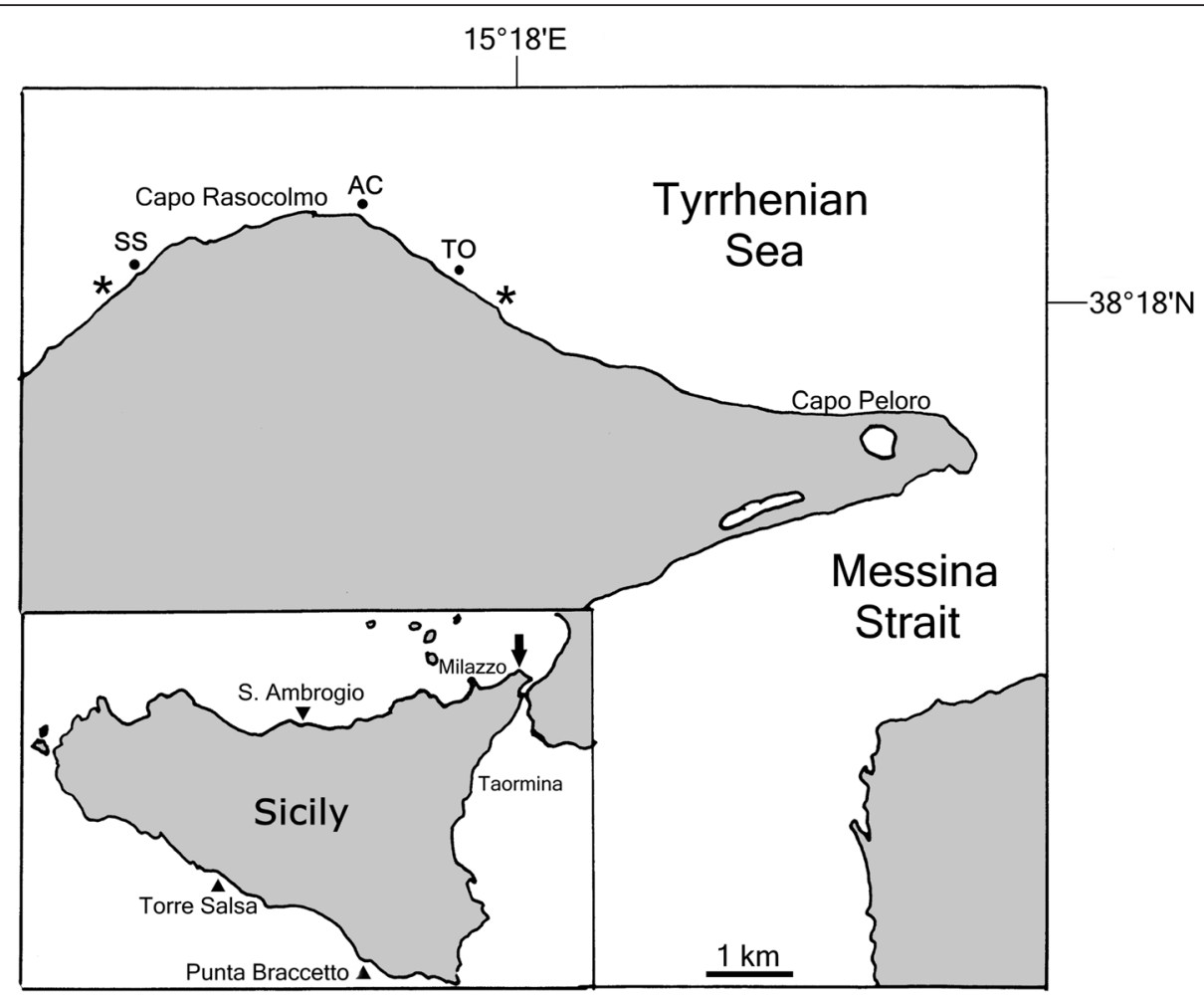

Fig. 2 Caulerpa taxifolia var. distichophylla in Sicily: the areas where the species is known to currently occur are indicated by triangles. An arrow indicates the current record. In the study area, dots represent sampling sites: San Saba (SS), Acqualadrone (AC) and Tono (TO). The asterisks delimit the invaded area

each site. The percentage cover (Fig. 3) decreased from $26 \%$ at San Saba to less than $8 \%$ at Tono B (Fig. 3), along to a W-E gradient that was more marked between Aqualadrone and Tono.

The biomass (Fig. 4) followed the same trend as the density, decreasing from S. Saba $\left(69.04 \mathrm{gm}^{-2} \pm 2.55 \mathrm{SE}\right)$ to Tono $\mathrm{B}$ (17.91 $\left.\mathrm{gm}^{-2} \pm 1.37 \mathrm{SE}\right)$, but showed the highest discontinuity between S. Saba and Acqualadrone (Fig. 4). This gradient, which does not seem related to depth, type or exposure of substratum, follows the prevalent eastwards coastal current, suggesting the associated fine sand deposits might favour the settlement of

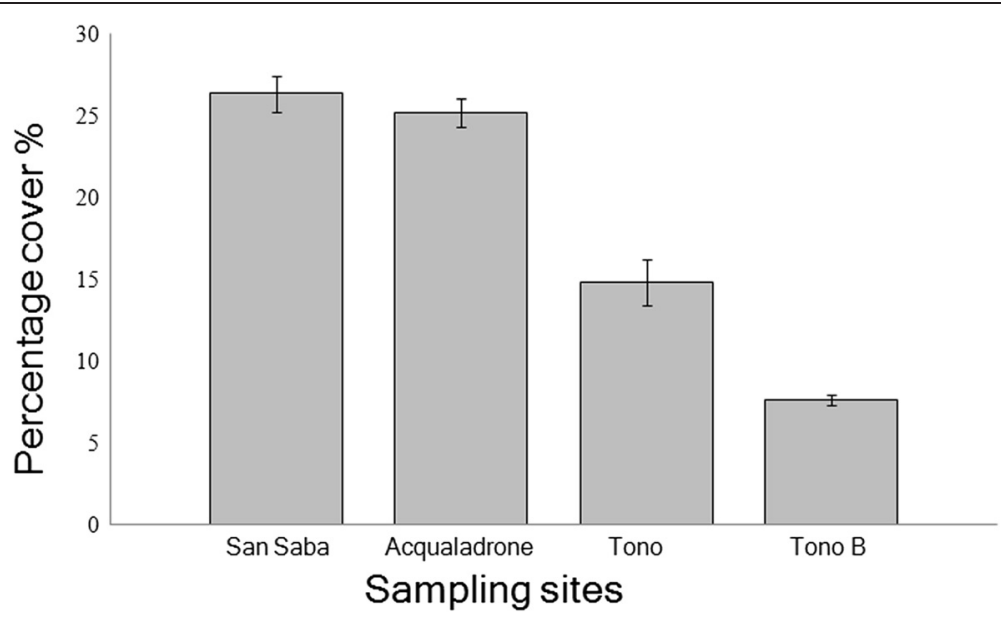

Fig. 3 Percentage cover $(20 \times 20 \mathrm{~cm}$ sampling surface) of Caulerpa taxifolia var. distichophylla in the different sampling sites (error bars=SE) in October 2013 (Six samples for each site. Twenty-four samples in total) 


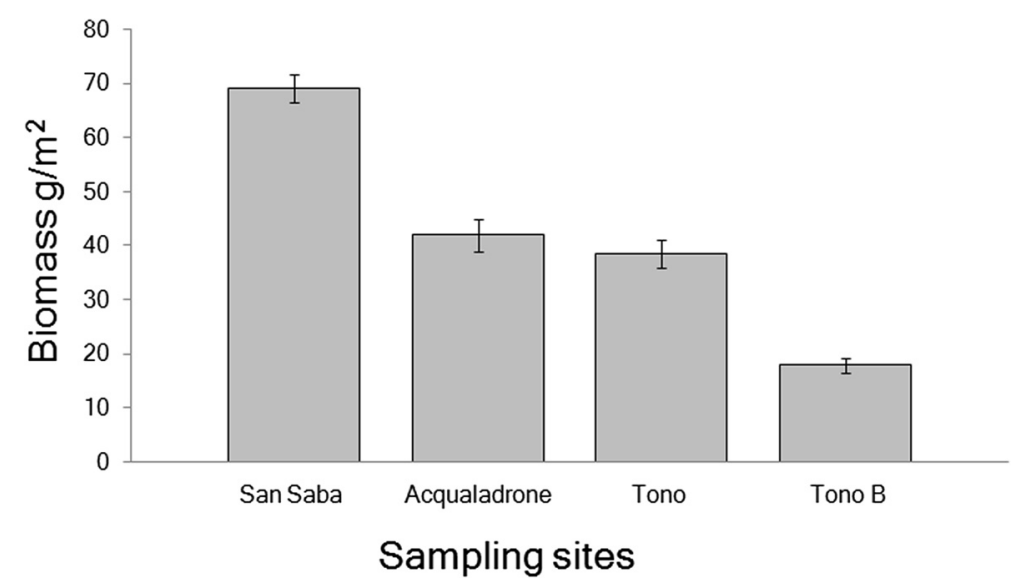

Fig. 4 Biomass ( $20 \times 20$ sampling surface) of Caulerpa taxifolia var. distichophylla in the different sampling sites (error bars SE) in October 2013 (Six samples for each site. Twenty-four samples in total)

the slender Caulerpa. Conversely, C. taxifolia colonises the central area of the Messina Strait (Orestano et al. 2001), where fine sedimentation is lacking. Despite the similar morphology, the two taxa are thus ecologically separated and well distinguished.

Ballast water unloading, ship traffic, aquarium trade and anchoring have been suggested as the main vectors of diffusion of C. taxifolia var. distichophylla in the Mediterranea Sea (Jongma et al., 2013; Musco et al., 2014). The current record, which is characterised by a marked discontinuity with respect to the recent report from northwestern Sicily (Musco et al., 2014), as well as from the earlier records from the Strait of Sicily (Jongma et al., 2013), is consistent with a human-mediated dispersal. In this respect, shipping traffic through the Strait of Messina might represent the main vector for the

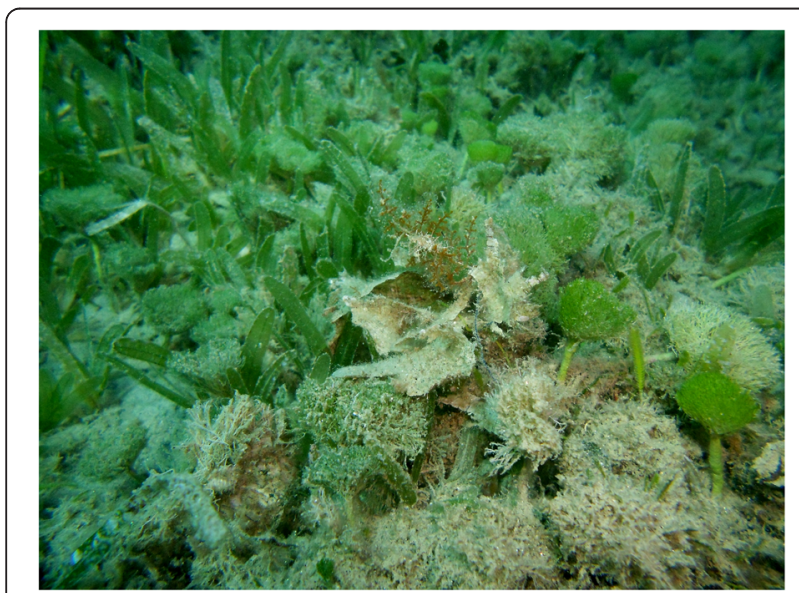

Fig. 5 Association between C. taxifolia var. distichophylla, Halophila stipulacea and Penicillus capitatus. (Tono B site, October 2013) northwards spread of the species. In the newly invaded area, which is a popular destination for tourists but lacks commercial shipping and fishing activities, only the anchoring of touristic vessels can be considered a probable vector of introduction.

In the Tono B site, the alga grows in association with the Lessepsian phanerogam Halophila stipulacea and the native tropical-subtropical green alga Penicillus capitatus Lamarck (Fig. 5). This pattern, which is new for the Mediterranean, reproduces a warm-water association described by Sangil et al. (2010) in the Canary Islands, suggesting a global change-mediated reorganisation of Mediterranean benthic assemblages. This association has not been described in the literature for C. taxifolia var. distichophylla, and involves the co-occurrence of alien and native species, whose dynamics and relationships will be the subject of further notes.

\section{Acknowledgements}

The authors would like to thank G. Fasano and G. Scarfi for their help in sampling.

\section{Availability of data and materials}

This paper is the first part of a research project. The autors will publish the whole data set at a later time.

\section{Authors' contributions}

MP, SG and NS designed the field surveys. MP and SG carried out the sampling. CB carried out the morphological analysis. MP drafted the manuscript, SG contributed to the manuscript drafting. All authors read and approved the final manuscript.

\section{Competing interests}

The authors declare that they have no competing interests.

Received: 17 May 2016 Accepted: 3 June 2016 Published online: 20 July 2016 


\section{References}

Azzaro F, Decembrini F, Raffa F, Crisafi E. Seasonal variability of phytopankton fluorescence in relation to the Straits of Messina (Sicily) tidal upwelling. Ocean Sci. 2007:3:451-60.

Bianchi CN, Morri C, Chiantore M, Montefalcone M, Parravicini V, Rovere A. Mediterranean Sea biodiversity between the legacy from the past and a future of change. Life in the Mediterranean Sea: a look at habitat changes. New York: Nova; 2012. p. 1-55.

Ceccherelli G, Cinelli F. Short-term effects of nutrient enrichment of the sediment and interactions between the seagrass Cymodocea nodosa and the introduced green alga Caulerpa taxifolia in a Mediterranean bay. J Exp Mar Biol Ecol. 1997;217:165-77.

Cevik C, Yokes MB, Cavas L, Erkol LI, Derici OB, Verlaque M. First report of Caulerpa taxifolia (Bryopsidales, Chlorophyta) on the Levantine coast (Turkey, eastern Mediterranean). Estuar Coast Shelf Sci. 2007:74:549-56.

Cicek B. First report of Caulerpa taxifolia var. distichophylla (Sonder) Verlaque, Huisman \& Procaccini (Caulerpaceae, Chlorophyta) from Northern Cyprus. Marseille France: Proceeding of the fortieth CIESM Congress; 2013.

Giacobbe S, Spanò N, Manganaro A. Le praterie di Posidonia Oceanica (L.) Delile nello Stretto di Messina: stato delle conoscenze e prospettive. Riserva Naturale di Capo Rizzuto, Le Castella: Proceeding of the first workshop "Le praterie di Posidonia Oceanica: Metodi di controllo ed esperienze"; 2001. p. 57-66.

Jongma DN, Campo D, Dattolo E, D'esposito D, Duchi A, Grewe P, Huisman J, Verlaque M, Yokes MB, Procaccini G. Identity of a slender Caulerpa taxifolia strain introduced into the Mediterranean Sea. Bot Mar. 2013;56(1):27-39.

Mangialajo L, Chiantore M, Cattaneo-Vietti R. Loss of fucoid algae along a gradient of urbanisation, and structure of benthic assemblages. Mar Ecol Prog Ser. 2008;358:63-74.

Meinesz A, De Vaugelas J, Hesse B, Mari X. Spreading of the introduced tropical green alga, Caulerpa taxifolia in northern Mediterranean waters. J Appl Phycol. 1993;5:141-7.

Meinesz A, Belsher T, Thibaut T, Antolic B, Mustapha KB, Boudouresque CF, Chiaverini D, Cinelli F, Cottalorda JM, Djellouli A, El Abed A, Orestano C, Grau AM, Ivesa L, Jaklin A, Langar H, Massuti-Pascual E, Peirano A, Tunesi L, De Vaugelas J, Zavodnik N, Zuljevic A. The introduced green alga Caulerpa taxifolia continues to spread in the Mediterranean. Biological Invasion. 2001;3:201-10.

Musco L, Andaloro F, Mikac B, Mirto S, Vega Fernandez T, Badalamenti F. (2014) Concern about the spread of the invader seaweed Caulerpa taxifolia var. distichophylla (Chlorophyta: Caulerpales) to the Western Mediterranean. Mediterranean Marine Science 15, 532-538. doi:http://dx.doi.org/10.12681/ mms.742.

Orestano C, Pirrotta M, Ammirato E. Spread of Caulerpa taxifolia in Sicily and Calabria (Italy). In: Gravez V, Boudouresque CF, Meinesz A, Scabbia G, editors. Proceeding of the Fourth International Workshop on Caulerpa taxifolia. Lerici. Marseille: GIS Posidonie; 2001. p. 78-84

Piazzi L, Balata D, Ceccherelli G, Cinelli F. Comparative study of the growth of the two co-occurring introduced green algae Caulerpa taxifolia and Caulerpa racemosa along the Tuscan coast (Italy, western Mediterranean). Cryptogam Algol. 2001;22:459-66

Piazzi L, Meinesz A, Verlaque M, Akali B, Antolic B, Argyrou M, Balata D, Ballesteros E, Calvo S, Cinelli F, Cirik S, Cossu A, D'Archino R, Djellouli AS, Javel F, Lanfranco E, Mifsud C, Pala D, Panayotidis P, Peirano A, Perfent G, Petrocelli A, Ruitton S, Zuljevic A, Ceccherelli G. Invasion of Caulerpa racemosa var. cylindracea (Caulerpales, Chlorophyta) in the Mediterranean Sea: an assessment of the spread. Cryptogam Algol. 2005;26:189-202.

Sangil C, Sansòn M, Afonso-Carrillo J, Martìn-Garcìa L. Extensive off-shore meadows of Penicillus capitatus (Udoteaceae, Chlorophyta) in the Canary Islands (eastern Atlantic Ocean). Bot Mar. 2010;53:183-57.

Schembri PJ, Barbara J, Deidun A, Lanfranco E, Lanfranco S. It was only a matter of time: occurrence of Caulerpa taxifolia (Vahl) C. Agardh var. distichophylla (Sonder) Verlaque, Huisman and Procaccini in the Maltese Islands (Chlorophyta, Ulvophyceae, Caulerpaceae). Biolnvasion Records. 2015;4:9-16.

Verlaque M, Afonso-Carrillo J, Gil-Rodriguez MC, Durand C, Boudouresque CF, Le Parco Y. Blitzkrieg in a marine invasion: Caulerpa racemosa var. cylindracea (Bryopsidales, Chlorophyta) reaches the Canary Islands (northeast Atlantic). Biol Invasions. 2004;6:269-81.

Villele X, Verlaque M. Changes and degradation in a Posidonia oceanica bed invaded by the introduced tropical alga Caulerpa taxifolia in the northwestern Mediterranean. Bot Mar. 1995;38:79-87.

\section{Submit your next manuscript to BioMed Central and we will help you at every step:}

- We accept pre-submission inquiries

- Our selector tool helps you to find the most relevant journal

- We provide round the clock customer support

- Convenient online submission

- Thorough peer review

- Inclusion in PubMed and all major indexing services

- Maximum visibility for your research

Submit your manuscript at www.biomedcentral.com/submit

) Biomed Central 